\title{
The Water-Energy-Carbon Nexus: Optimising Rainwater Harvesting in Mexico City
}

\author{
M. Carmen Valdez ${ }^{1} \cdot$ Ilan Adler ${ }^{1} \cdot$ Mark Barrett $^{2}$ • \\ Ricardo Ochoa ${ }^{3} \cdot$ Angel Pérez $^{3}$
}

Received: 8 July 2015 / Accepted: 18 January 2016/Published online: 18 February 2016

(C) The Author(s) 2016. This article is published with open access at Springerlink.com

\begin{abstract}
This study compares greenhouse gases emissions and energy consumption of buildings supplied by the municipal water grid in Mexico City against different configurations of rainwater harvesting systems. A comparative simulation model was built for this purpose. Life-cycle assessment methodology was used to embrace impacts not only from operation (e.g. pumping energy) but also from building the system (e.g. materials, their transportation, etc.). This analysis is essential to improve Mexico City's water management. The city's aquifer is overexploited, which has caused land subsidence; the city is prone to flooding for being located in an endorheic basin and highly urbanised; it consumes $1.23 \mathrm{kWh} / \mathrm{m}^{3}$ to supply water to the municipal grid (65\% of it to import $18 \%$ of its water demand from neighbouring basins); and between $30 \%$ and $50 \%$ of this water is lost through grid leakages. The model was used to analyse eleven different types of buildings. Results proved that rainwater harvesting can reduce greenhouse gases emissions in Mexico City and three of the four harvesting scenarios also aid at mitigating flooding risk.
\end{abstract}

Keywords Rainwater harvesting · Life-cycle assessment · Carbon emissions · Energy consumption $\cdot$ Water management $\cdot$ Flood mitigation

Electronic supplementary material The online version of this article (doi:10.1007/s40710-016-0138-2) contains supplementary material, which is available to authorized users.

Ilan Adler

ilan.adler.09@ucl.ac.uk

1 Civil, Environmental and Geomatic Engineering Department, University College London, Gower Street, London WC1E 6BT, UK

2 Energy Institute, University College London, Upper Woburn Place, London WC1H 0NN, UK

3 Mario Molina Centre for Strategic Studies on Energy and Environment, Prolongación Paseo de los Laureles 458, Despacho 406, Colonia Bosques de las Lomas, 05120 Cuajimalpa, CP, Mexico 


\section{Introduction}

Climate change (global warming) is expected to increase mean temperatures between 2 to $4{ }^{\circ} \mathrm{C}$ and decrease annual precipitation between 5 and $20 \%$ in Mexico (Romero Lankao 2010). The corresponding effects can be increased water stress due to larger dry seasons, and augmented intensity of individual rainfall events due to higher tropical cyclone activity (Bates et al. 2008), i.e. less rainfall but more concentrated. For this reason, it is important to adapt Mexico City to climate change effects, particularly intense rainfalls and water scarcity, and decrease its greenhouse gases (GHG) emissions.

Rainwater harvesting (RWH) has proved to be a measure to mitigate flood risk: it decreases rainfall peak discharges, runoff volumes and velocity (Gwenzi and Nyamadzawo 2014). Several studies state that it can also curtail hydraulic stress by saving municipal water, reducing groundwater extraction and water pollution (Burns et al. 2010; UNEP 2015; Zhang 2009), as well as providing a valuable alternate source of drinking water when adequately treated (Adler et al. 2013; Adler et al. 2011). Under certain circumstances it can also reduce energy consumption and associated GHG emissions (Vieira et al. 2014; Ward et al. 2012).

Life-cycle assessment (LCA) methodology can be used to evaluate the burden of RWH construction materials and its energy requirements, providing a fair comparison between RWH systems and other water management options. This methodology has been used to compare water conservation scenarios in Toronto, Canada, finding that RWH helps reduce hydraulic stress (Racoviceanu and Karney 2010). Another study used LCA to compare the environmental impacts of different RWH options in Mediterranean climates (Angrill et al. 2011).

RWH is of particular importance for Mexico City because its aquifer has been overexploited for the last 50 years (CONAGUA 2012) and the city is prone to flooding due to its location in an endorheic basin, the constant spread of the paved city, erosion, and the reduction of infiltration capacity (Burns et al. 2010). Furthermore, the city's water system is energy and carbon intensive to a high degree, as explained in the next paragraphs.

According to a study from the Mario Molina Centre (Centro Mario Molina 2011), $82 \%$ of fresh water is supplied from the overexploited aquifer below the city and $18 \%$ is imported from other basins through the Lerma-Cutzamala system. The electricity consumption of the former is between $0.25 \mathrm{kWh} / \mathrm{m}^{3}$ and $0.53 \mathrm{kWh} / \mathrm{m}^{3}$ and the latter $4.54 \mathrm{kWh} / \mathrm{m}^{3}$; meaning that the Lerma-Cutzamala system consumes $65.5 \%$ of the electricity required but contributes only $18 \%$ of the water supplied, resulting in an average energy consumption to $1.23 \mathrm{kWh} / \mathrm{m}^{3}$ (Centro Mario Molina 2011).

Additionally, the city's drainage system consumes $0.048 \mathrm{kWh} / \mathrm{m}^{3}$ to pump sewage across and outside the basin and $2.45 \mathrm{kWh} / \mathrm{m}^{3}$ to treat wastewater (Centro Mario Molina 2011). At the time of writing only $11 \%$ of the total wastewater volume is treated (PIGOO 2013); the Atotonilco treatment plant under construction is expected to increase this to $60 \%$ (Chávez 2014).

Overexploiting the aquifer has caused land subsidence (Figueroa 1984), which has damaged the water network and drainage system, causing leakages in the former and an increased need for pumping in the latter (SACM 2012). Because of this, it is estimated that $35 \%$ of the water supplied to the grid is lost through leakage before reaching dwellings (SACM 2012). This means that $1.54 \mathrm{~L}$ have to be supplied to the grid for each litre consumed by final users, and that the energy required increases from $1.23 \mathrm{kWh} / \mathrm{m}^{3}$ at the city boundary to $1.90 \mathrm{kWh} / \mathrm{m}^{3}$ when delivered to consumers. Table 1 shows a comparison of European LCA of urban water systems with Mexico City.

In addition to the energy consumed by the municipal and national water utilities, end users also need to pump water. The municipal water network does not provide water at the pressure 
Table 1 Comparison of energy consumptions and Global Warming Potenstial (GWP) of different urban water systems

\begin{tabular}{|c|c|c|c|c|c|c|c|c|}
\hline \multirow[b]{2}{*}{ Stage } & \multirow[b]{2}{*}{ Unit } & & \multicolumn{2}{|c|}{$\begin{array}{l}\text { Aveiro, } \\
\text { Portugal }\end{array}$} & \multicolumn{2}{|c|}{ Tarragona, Spain } & \multicolumn{2}{|c|}{ Mexico City } \\
\hline & & & $\begin{array}{r}\text { Lemos } \\
\quad(201\end{array}$ & & $\begin{array}{r}\text { Amores } \\
(2013\end{array}$ & & $\mathrm{CMM}$ & 2011) ${ }^{a}$ \\
\hline Water abstraction & $\mathrm{kWh} / \mathrm{m}^{3}$ & & 0.64 & & 0.29 & & 1.9 & \\
\hline Water treatment & $\mathrm{kWh} / \mathrm{m}^{3}$ & & & & 0.07 & & & \\
\hline Water distribution & $\mathrm{kWh} / \mathrm{m}^{3}$ & & 0.43 & & 0.48 & & & \\
\hline Sewage collection & $\mathrm{kWh} / \mathrm{m}^{3}$ & & & & & & 0.48 & \\
\hline Wastewater treatment ${ }^{b}$ & Proportion treated & $\mathrm{kWh} / \mathrm{m}^{3}$ & $100 \%$ & 0.63 & $100 \%$ & 1.09 & $11 \%$ & 2.45 \\
\hline Total & $\mathbf{k W h} / \mathbf{m}^{3}$ & & 1.7 & & 1.9 & & 2.6 & \\
\hline Water losses & Percentage & & 38 & & 20 & & 35 & \\
\hline GWP & $\mathrm{kg} \mathrm{CO}-\mathrm{Eq} / \mathrm{m}^{3}$ & & 1.6 & & 0.9 & & 2.1 & \\
\hline
\end{tabular}

\footnotetext{
${ }^{a}$ The Mexican case analyses only energy required for operations, it is not a LCA

${ }^{b}$ The European cases treat $100 \%$ of the water, whereas in Mexico city just $11 \%$ is treated (PIGOO 2013).

${ }^{\mathrm{c}}$ The Portuguese and Spanish studies consider emissions embodied in the infrastructure materials (piping), whereas the Mexican study reports only emissions related to the electricity consumed for operations. The differences in the GWP impacts are due mainly to the national electric mix carbon footprint, which is $60 \%$ larger in Mexico than in Spain and 33 \% larger than in Portugal (Itten et al. 2014)
}

needed to reach points of use due to the high amount of leakages in the grid (CONAGUA 2013; SACM 2012). Therefore underground storage tanks, header tanks and pumping equipment are standard in houses and buildings of Mexico City, as is required by the local norms (Gobierno 2004).

Acknowledging that Mexico City's hydraulic system consumes large quantities of electricity, that the city is prone to flooding, and that many buildings already have cisterns, pumps and header tanks, this study analyses the possibility of RWH as a measure to reduce electricity consumption, GHG emission and flooding risk. The assessment is based on LCA methodology. It estimates the best RWH configuration in terms of flood prevention, GHG emissions, energy demand and cost by comparing five different scenarios: one base scenario with no RWH and four different RWH scenarios.

\section{Methodology}

\subsection{Objective}

The aim of the study is to calculate and compare life-cycle GHG emissions, energy and costs of buildings supplied by municipal-water and different configurations of RWH systems in Mexico City.

\subsection{Methodology}

The methodology used was life-cycle assessment (LCA) based on ISO 14040 and ISO 14044. LCA was chosen because it embraces all processes during the lifespan of a system (raw materials, transportation, construction, operation, maintenance, and disposal), reflecting the 
effects of extra materials needed for RWH, extra energy for pumping and/or treating rainwater, and energy that can be saved from the municipal water network and drainage. The tool used was an original comparative model that calculates the life-cycle impacts of the five scenarios. The model was named RHO_mx (Rainwater Harvesting Optimisation Mexico) and can be accessed in Electronic supplementary material.

The system was defined as the building's water management system, which refers to the rainwater and municipal water that enters the building, its storage, possible treatment, pumping, distribution within the building and disposal (including energy required to convey it and treat it at municipal wastewater treatment plants). The construction and maintenance of the municipal water grid are not considered as part of the system since it is assumed that installing a RWH system does not affect the existing grid. The main functions of the system are to supply water for the uses inside the building and to manage rain falling onto the building's rooftop. The functional unit was defined as one cubic meter of water consumed by the building (regardless of the source). The system's lifespan was considered to be 40 years, though the lifespan of each component is considered individually when estimating materials' impacts.

Three key indicators were quantified in this study: Cumulative Energy Demand (CED), Global Warming Potential (GWP), and Net Present Value (NPV). CED refers to the primary energy consumed through the system's life-cycle per $\mathrm{m}^{3}$ of water consumed by the building, expressed in $\mathrm{kWh} / \mathrm{m}^{3}$; i.e. total energy by functional unit. Similarly, GWP refers to the quantity of GHG emitted by functional unit expressed in $\mathrm{kgCO}_{2} \mathrm{eq} / \mathrm{m}^{3}$. NPV refers to the lifecycle cost determined by the sum of the discounted cash flows resulting from each scenario.

The inventory is expressed as a matrix that shows all system's components to supply, store, treat, pump, distribute, and dispose water (rows down) in each life-cycle process (columns to the right), as shown in Table 2. Elements that remain constant were excluded, e.g. fixtures like toilets or basins, sewage drainpipes and distribution piping within each floor. Energy consumed by the municipal utility to supply water, and energy consumed by municipal wastewater treatment plants is considered as part of the system.

The authors focused in the present study on new buildings; but consider that retrofitting should be considered in the next versions of the model.

The inventory matrix is the model's core for calculating GWP, CED and costs. The model quantifies each component based on the building's characteristics and scenario (e.g. metres of polypropylene piping, cubic metres of reinforced concrete, etc.). LCA studies from databases Ecoinvent 3, Industry data 2.0 (SimaPro), ELCD 2.0, and the Inventory of Carbon and Energy (Hammond and Jones 2008) were used to estimate the energy and GHG emissions embodied in the materials conforming the system and its equipment's consumables. Data for reinforced concrete and commercial steel rods were adapted from the international databases to reflect Mexican processes and local electricity mix. GWP and CED values were divided by material's lifespan to obtain annual values and ease comparison.

The average transportation distance from manufacturing plants to the building was assumed to be $100 \mathrm{~km}$. GHG emissions per lorry type from the Greenhouse Gas Conversion Factor Repository (DEFRA 2014) were used due to the lack of information about Mexican freight transportation. Disposal impacts were limited to the transportation of materials to recycling facilities or final disposal sites, and do not account for the environmental impacts at landfill. Construction impacts were considered negligible (Devkota et al. 2013).

Operational impacts were calculated from the electricity consumed to pump and treat water in the building and the electricity consumed by the municipal utility to supply water, convey sewage and treat it, as is explained in the following paragraphs. The value of $0.79 \mathrm{kgCO}_{2} \mathrm{eq} /$ 


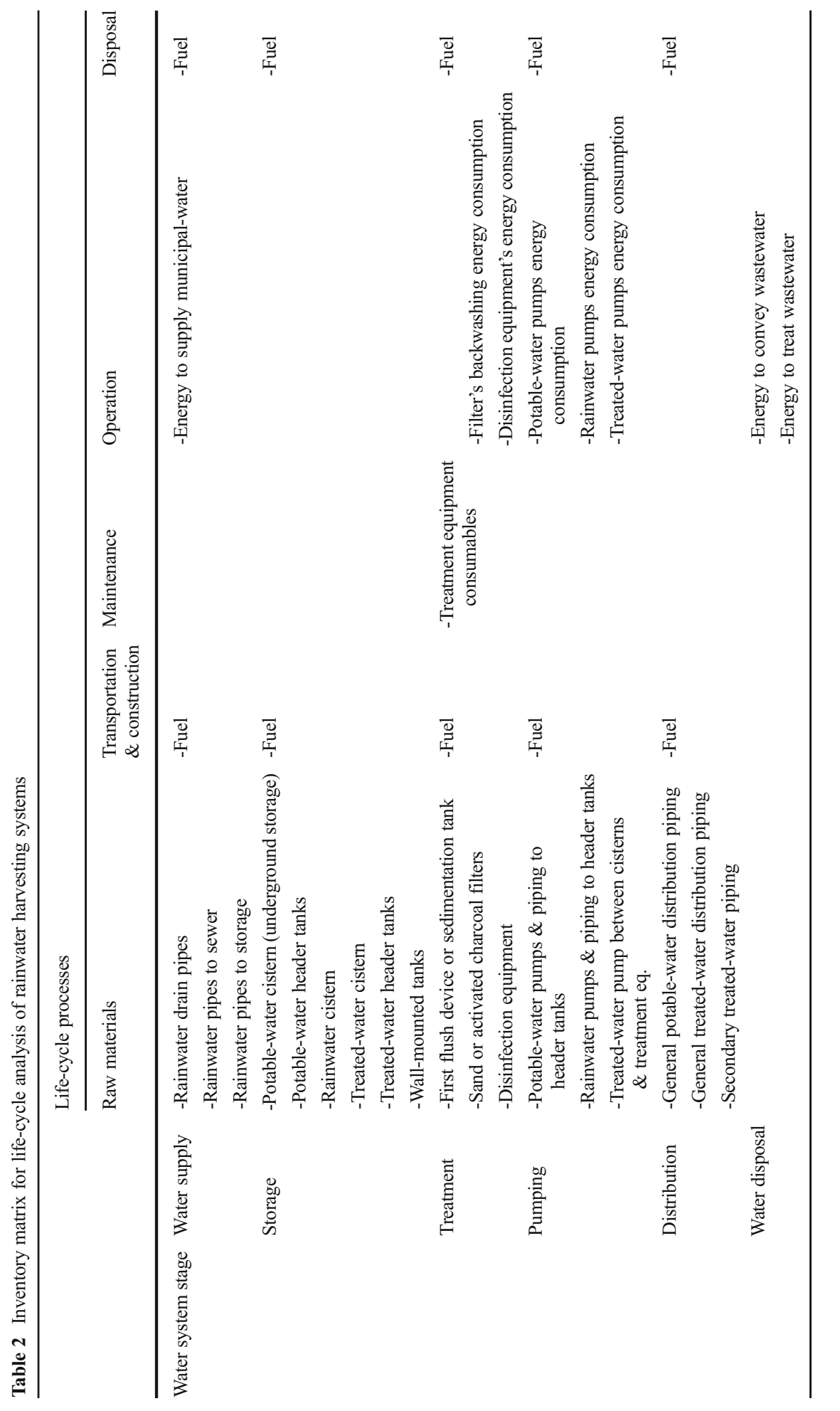


$\mathrm{kWh}$ of electricity produced, transmitted and distributed for the Mexican electricity mix published by the Paul Scherrer Institut (Itten et al. 2014) for 2008 was used to calculate GHG emissions from this electricity consumption.

The RHO_mx model calculated the building's water demand based on the minimum daily supply required by the local norms for housing, office and retail buildings (Gobierno 2004). It was assumed that the building is supplied by municipal water, and that the municipal water consumption equals the water demand minus the rainwater harvested; for the base scenario municipal water was considered the only source. The annual rainwater harvested volume, was calculated with local rainfall data. The average annual rainfall in Mexico City is $700 \mathrm{~mm} / \mathrm{m}^{2}$; but $68 \%$ of it occurs between June and September (CONAGUA 2009) and rainfall varies from 500 to $1600 \mathrm{~mm} / \mathrm{m}^{2}$ across the city (INEGI 2013). It was decided to use daily data from one station over the monthly city averages for greater precision and to avoid oversizing, as will be explained further below. Daily rainfall data from 1980 to 2010 from station 9029 Gran Canal $\mathrm{km} 06+250$ were used; its standard annual rainfall is $608 \mathrm{~mm} / \mathrm{m}^{2}$ (CONAGUA 2010). This meteorological station was selected for being representative of rainfall in highly populated areas of Mexico City and for having complete daily data for 30 years.

The RHO_mx model also calculates the amount of water input to the drainage system by summing the building's wastewater (which equals the water demand) and the rainwater sent to the sewer. It was assumed that all rain falling onto the rooftop was sent to the sewer when it was not harvested; in RWH scenarios only storage overflow was accounted as sewage.

These volumes of municipal water consumption and water input to sewers were multiplied by the energy costs of the municipal water system and wastewater treatment percentage given in the introduction: $1.90 \mathrm{kWh} / \mathrm{m}^{3}$ for municipal water supplied to the dwelling, $0.048 \mathrm{kWh} / \mathrm{m}^{3}$ for sewage pumped through the drainage, $2.45 \mathrm{kWh} / \mathrm{m}^{3}$ for wastewater treated (Centro Mario Molina 2011), and $11 \%$ of wastewater currently treated (PIGOO 2013).

The RHO_mx model calculates the pump and water treatment equipment capacities based on the building's characteristics and scenario (e.g. building's height, water demand, treating volume). Deep bed sand filtration with backwashing and silver ion disinfection were the rainwater treatment methods selected for this study. The model calculates the energy consumed to pump and treat water based on the water volume and the equipment's characteristics given by the manufacturer. For simplification purposes, head loss caused by treatment equipment was excluded.

The NPV was calculated using a real annual discount rate of $1.07 \%$, which stems from the difference between an annual inflation rate of $4.07 \%$ and an annual interest rate of $-3.00 \%$. The former was published by the Mexican Central Bank for the general index of the July 2014 National Prices and Costs Index (Banco de México 2014a). The latter corresponding to the annual rate for CETES-336 published by the Mexican Central Bank (Banco de México 2014b). A negative NPV means it is not economically viable.

Initial investment, annual maintenance expenses, and expected savings or extra costs in energy and water bills are also calculated and compared against the scenario without RWH. Water and energy tariffs excluding subsidies are used to reflect real costs. The domestic high consumption tariff (DAC tariff) for August 2014 central region (CFE 2014 ) is used to calculate energy bills, and 2014 domestic tariffs before subsidy (Gobierno 2013) are used to estimate water bills. Domestic tariffs are used for all building typologies to simplify the model. 


\subsection{Scenarios}

One scenario with no RWH (scenario BASE) and four harvesting scenarios (RW1, RW2, RW3, and RWg) were defined (see Fig. 1). Scenario BASE, the base case, is supplied only by municipal-water (MW) while rainwater (RW) is conducted directly to the sewer. Municipal water is stored in an underground potable water deposit (PW cistern) and then pumped to header tanks on the building's roof to be distributed by gravity to the different points of use. This scenario represents a standard building's water system for Mexico City.

Scenario RW1 harvests rainwater for non-potable uses. It requires a separate RW cistern, treatment equipment, a cistern to store the treated rainwater (TW cistern), pumps, header tanks, and an independent distribution piping system. This scenario represents the most common RWH arrangement in Mexico City.

Scenarios RW2 and RW3 treat rainwater to potable standards. In scenario RW2, rainwater collected from the rooftop is stored in a RW cistern, then treated, purified and transferred into the PW cistern where municipal water is stored too. Scenario RW3 uses the same cistern to store rainwater and municipal water, hence their combined volume is treated to the same drinking water standard before being distributed with the same pump, pipes and tanks used in scenario BASE.

Scenario RWg is a gravity-fed rainwater distribution system for non-potable uses. Instead of having an underground storage and then pumping to header tanks, several wall-mounted tanks are installed in different storeys to supply water by gravity. This scenario is based on the
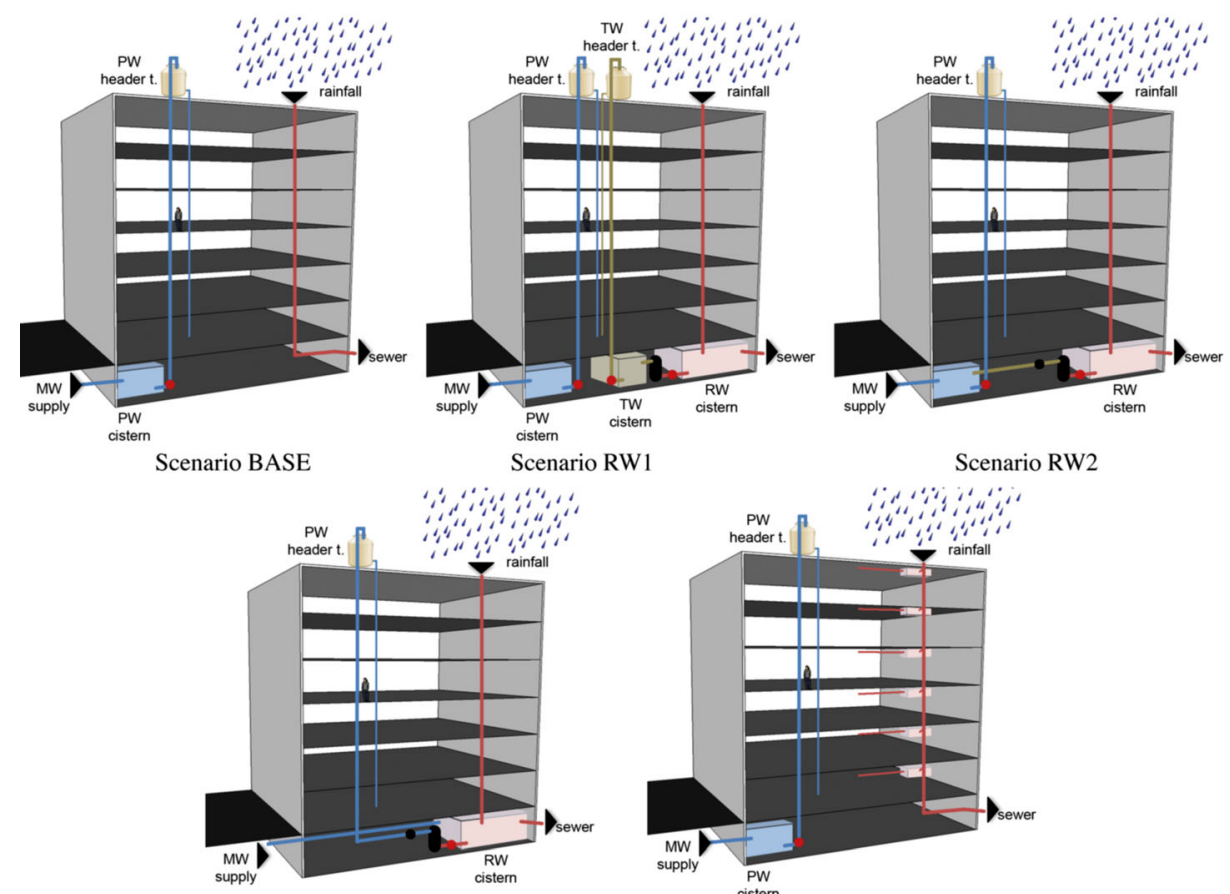

Scenario RW3

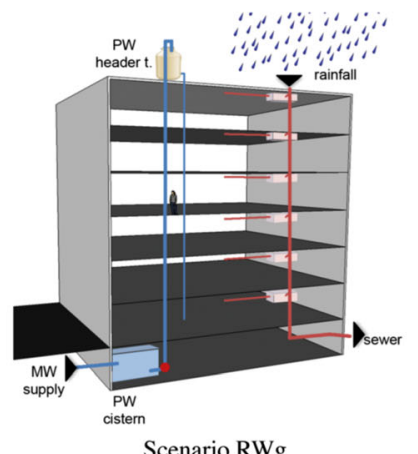

Fig. 1 Schematic representation of the five scenarios 
experimental prototype developed by MWH, Dwr Cymru Welsh Water and Aqualogic (Fitzpatrick 2009).

\section{Model}

RHO_mx is a simulation and optimisation model built in MS Excel. It simulates water demand and rainwater harvested in a given building, optimising the RW storage size and comparing the key indicators GWP, CED, and NPV of each of the five scenarios. RHO_mx was used to analyse eleven standard housing, office and retail buildings in Mexico City, from a single house to high-rise buildings.

RW storage size is optimised to minimise the GWP of the building's water system. The objective function is to minimise GWP with two constraints: first to comply with the minimum volume required to retain heavy rainfalls in the plot (required by the General Ordinance Norms (Gobierno 2005) and calculated according to the Guides for Alternative Rainwater Systems provided by the Mexico City Water System authority (SACM 2014), and second to stay below the maximum available volume due to space constraints. The RW cistern in scenario RW3 must store three times the daily water demand in addition to the minimum volume to cope with heavy rainfalls, for this scenario has only one cistern for municipal water and rainwater. Results of minimising NPV or CED can also be observed in the model, though this study focused on minimising GWP.

RHO_mx simulates daily water flow in the rainwater storage during 30 consecutive years using daily rainfall data from the meteorological station 9029 (CONAGUA 2010). It determines the optimum storage size and calculates the average annual volume of rainwater harvested with this storage. The first approach to the methodology used monthly rainfall data, but this resulted in larger optimal storages than using daily data (from $40 \%$ to $85 \%$ larger). This was because storing monthly differences between harvested rainwater and water demand required a larger volume than storing the biggest daily difference.

The model can be used to analyse other cities or locations by modifying the corresponding input information.

\section{Results and Discussion}

\subsection{Scenario BASE}

According to the RHO_mx model, buildings in Mexico City supplied only by municipal water emit between 1.96 and $2.10 \mathrm{kgCO}_{2} \mathrm{eq} / \mathrm{m}^{3}$. More than $93 \%$ of the $\mathrm{GHG}$ emitted by such buildings occurs during operation; materials used to construct the building's water system engender less than $7 \%$. Emissions from transportation, construction and disposal are negligible.

Between 2.42 and $2.58 \mathrm{kWh} / \mathrm{m}^{3}$ are required to operate the building's water management system (internal to pump water to header tanks, and external to supply municipal water, convey and treat wastewater). Energy consumed to supply the building with municipal water accounts for more than $72 \%$ of the energy consumed during the system's life-cycle and over $71 \%$ of its GHG emissions, making it the highest contributor to the system's GWP. Between $13 \%$ and $16 \%$ of the energy belongs to municipal sewer and wastewater treatment plants, and between $5 \%$ and $13 \%$ to pumping water to header tanks. 


\subsection{Scenarios Comparison}

Scenario BASE (no RWH) resulted the highest in terms of GWP for all buildings, and scenario RW1 (non-potable RWH) the second highest in 10 of the 11 buildings. All RWH configurations analysed in this study decreased GHG emissions compared to scenario BASE. Scenarios RW3 and RWg yielded the highest GWP reductions.

All RWH scenarios increased material GHG emissions compared to scenario BASE. Storage, pumping equipment and PVC drainpipes were the main contributors. But GHG emission reductions in operation offset these increments in all scenarios and all buildings. GHG emissions from operation decreased because energy increments for pumping and treating rainwater were lower than energy savings due to displacing municipal water with rainwater and minimising rainwater input to the municipal drainage. Figure 2 depicts the GWP reduction that each scenario yields when compared to scenario BASE; Table 3 summarises the resulting rainwater storage size by scenario.

RWH resulted in GHG emissions reductions even though the annual rainwater harvested volume covers less than $30 \%$ of the annual water demand in all analysed buildings and scenarios.

Scenario RWg (gravity-fed RWH) was the highest GHG saving option for high-rise buildings (5 or more storeys), with savings ranging from $3.1 \%$ to $8.5 \%$ of the GWP. But it does not comply with the minimum storage volume required to retain peak rain events, i.e. wall-mounted tanks do little to mitigate flooding risk. The storage volume for this RWH configuration is limited by the available area in the building's façade, which in the study was assumed as $15 \%$ of the building's width in each floor.

Scenario RW3 (potable RWH with one cistern) yielded the highest GWP reductions for low-rise buildings, between $7.1 \%$ and $18.4 \%$, and the second highest for the rest of the buildings just after scenario RWg. Unlike scenario RWg, rainwater storage volume in scenarios RW1, RW2 and RW3 is enough to retain heavy rainfalls.

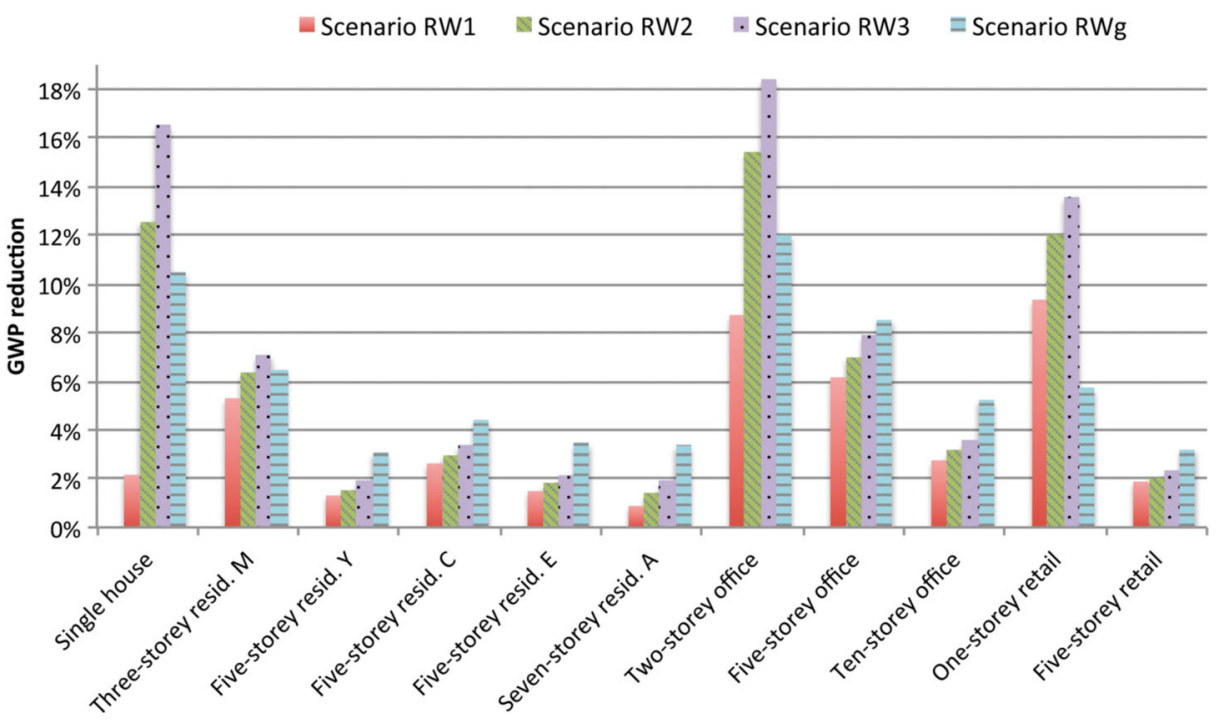

Fig. 2 Global Warming Potential (GWP) reduction by scenario and building 


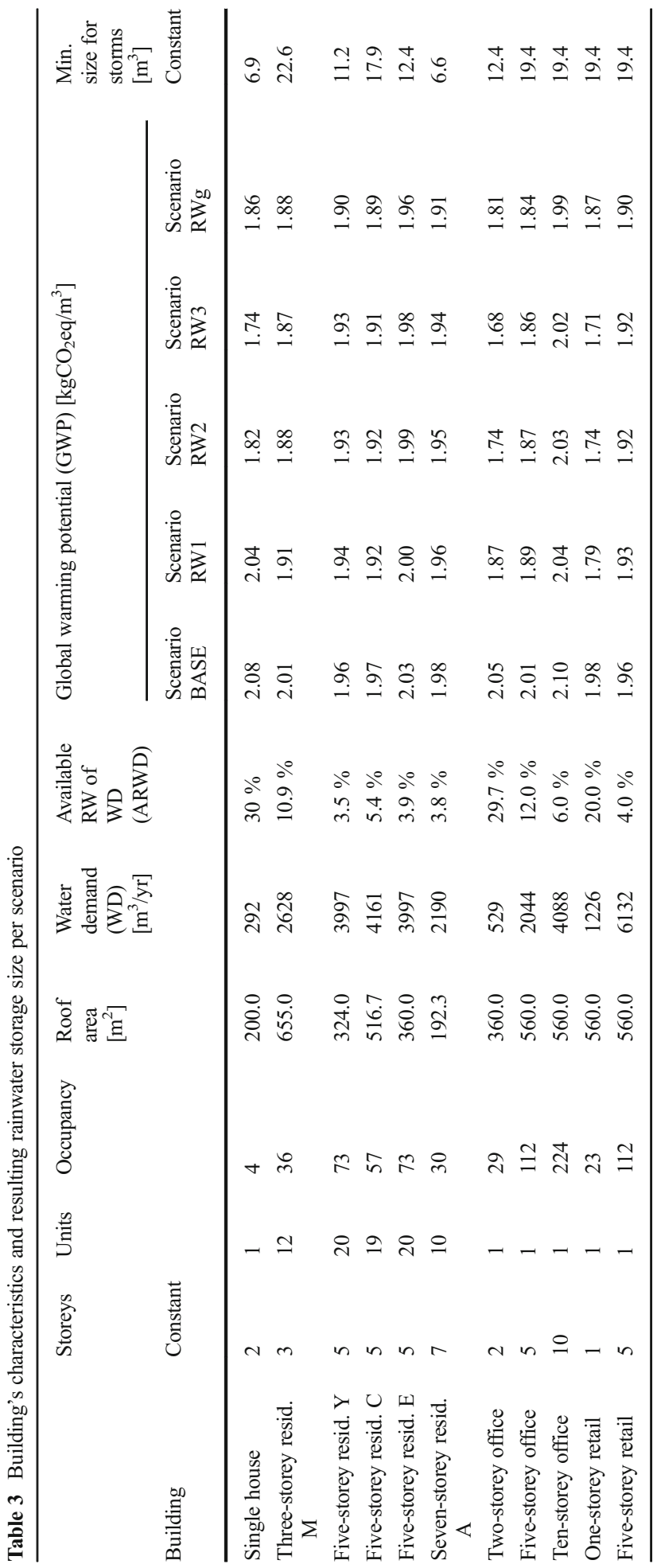


The ratio of available-rainwater to water-demand (ARWD) refers to the percentage that rainfall collected on the building's rooftop represents of its total water demand, i.e. the maximum percentage that rainwater could cover from water demand if all rainfall could be harvested. Figure 3 shows there is a positive relation between ARWD ratio and GWP reduction: the higher the building's ARWD, the higher the energy and GWP reduction for harvesting rain. Buildings with low ARWD ratio show similar GWP reductions for scenarios RW1, RW2, and RW3, whereas in buildings with high ARWD ratio the difference between scenarios increases significantly, being scenario RW3 the best GWP reducer of these three scenarios always. RW harvesting capacity in scenario RWg is limited by the building's height; therefore it has no standard curve for the ARWD ratio.

\subsection{Rainwater-Storage Size}

It was found that in scenarios RW1, RW2, and RW3, the RW storage capacity was determined by the volume required to retain peak rain events, this volume being larger than the size minimising GWP in all analysed buildings. RW cistern sizes varied from $6.6 \mathrm{~m}^{3}$ to $22.6 \mathrm{~m}^{3}$ in scenarios RW1 and RW2, which is approximately equal to 0.035 times the catchment area. In scenario RW3 these volumes increased to $9.3 \mathrm{~m}^{3}$ and $69.8 \mathrm{~m}^{3}$ respectively (35\% to $300 \%$ larger), for having only one cistern for both municipal water and rainwater.

The effect of RW storage size on GWP, CED and cost was analysed. It was found that CED and GWP curves decrease sharply when the RW storage is added and starts increasing in size, but after reaching the minimum CED and GWP the curves are almost flattened. On the other hand, NPV becomes positive as storage size increases until it reaches a size that harvests more than $95 \%$ of the available rainwater, after that NPV becomes smaller or even negative, as shown in Fig. 4. In some buildings NPV never becomes positive, as it will be explained further in this document, but it follows the same curve. This means that a larger storage size can be

Fig. 3 Global Warming Potential (GWP) reduction by availablerainwater as a fraction of water demand (ARWD)

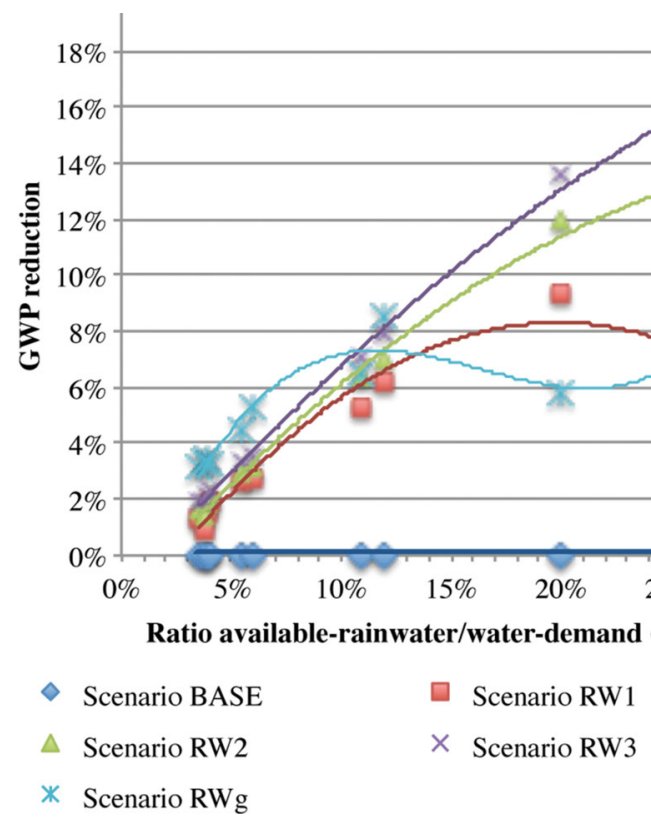




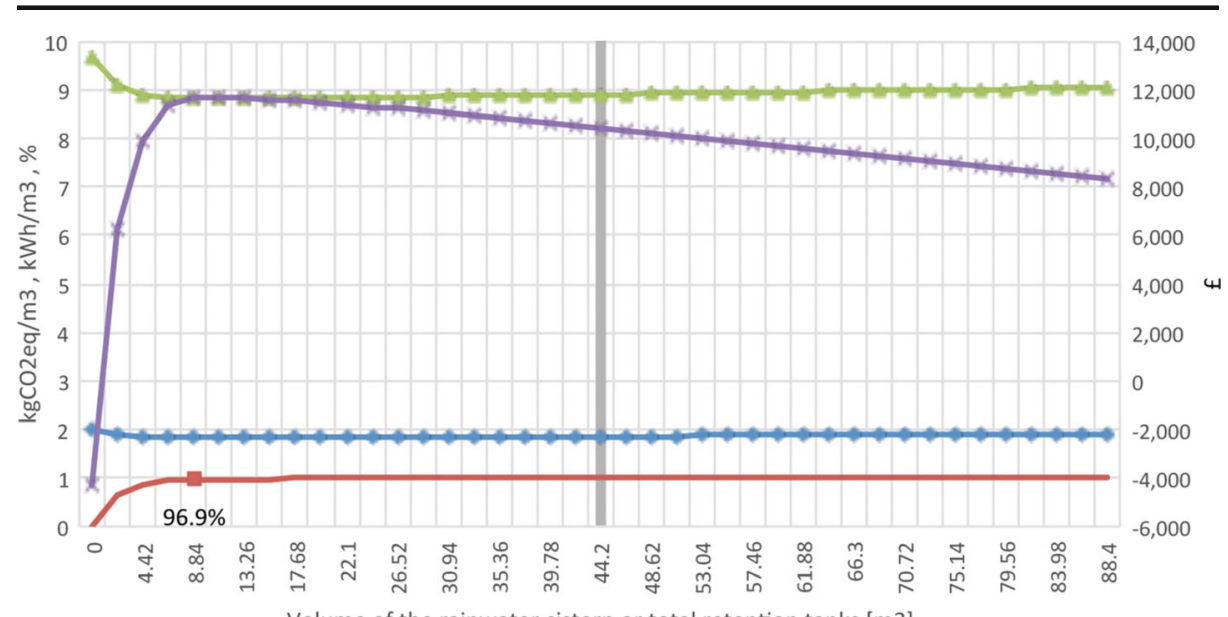

Volume of the rainwater cistern or total retention tanks [m3]

Selected size

- Cumulative Energy Demand (CED) [kWh/m3]

—Global Warming Potential (GWP) [kgCO2e/m3]

$\because$ Net Present Value (NPV) [f]

RW harvested from available RW [\%]

Fig. 4 Global Warming Potential (GWP), Cumulative Energy Demand (CED) and Net Present Value (NPV) variations by rainwater-deposit size in the three-storey residential building

selected to cope with dry years having little effect on GWP and CED, but a negative effect on NPV if it is harvesting above $95 \%$ of the available rainfall.

In scenario RWg, the maximum space available was lower than the minimum storage size to mitigate flooding risk in all the analysed buildings. Buildings with low ARWD ratio (lower than $6 \%$ ) are likely to harvest more than $90 \%$ of the available rainfall but never big enough to retain peak rainfalls. Storage size in scenario $\mathrm{RWg}$ ranged between 0.7 and $8.3 \mathrm{~m}^{3}$.

\subsection{Rainwater Uses}

Scenarios RW2 and RW3 (potable RWH with separate and mixed cisterns correspondingly) showed that more than $95 \%$ of the available rainfall could be used when rainwater is treated to potable standards. On the other hand, this figure ranged from $62 \%$ to $99 \%$ in scenario RW1 where rainwater is limited to non-potable uses.

Even though the available RW covers less than $30 \%$ of the building's water demand, which is less than the annual non-potable water demand (assumed as $33 \%$ of water demand), treating rainwater to potable standards gives the opportunity to consume more rainwater during the rainy season, therefore displacing more municipal water annually.

Furthermore, making rainwater potable requires less infrastructure than when it is limited to non-potable uses. Systems treating rainwater to potable standards require disinfection, which indeed adds more elements to the system and energy consumption, but once rainwater is potable it can be pumped and conveyed using the same infrastructure originally installed for the municipal water supply, saving the construction and operation of independent pumps, header tanks and piping for non-potable water supply, i.e. materials' savings in pumps, piping 
and storage offset disinfection equipment increments. For this reason, scenario RW1 yielded more GHG emissions than scenarios RW2 and RW3.

Additional energy needed to purify rainwater accounts for less than $0.1 \%$ of the total energy consumed to operate the system.

\subsection{Energy}

CED in scenario BASE ranged between 9.41 and $10.06 \mathrm{kWh} / \mathrm{m}^{3}$ (primary energy). As previously explained, operational electricity consumption (between 2.42 and $2.58 \mathrm{kWh} / \mathrm{m}^{3}$ in scenario BASE) is the main GWP and CED contributor. Operational electricity consumption in scenario RW1 ranged between 2.01 and $2.46 \mathrm{kWh} / \mathrm{m}^{3}$, scenario RW2 between 1.88 and $2.46 \mathrm{kWh} / \mathrm{m}^{3}$, scenario RW3 between 1.84 and $2.45 \mathrm{kWh} / \mathrm{m}^{3}$, and scenario RWg between 2.12 and $2.43 \mathrm{kWh} / \mathrm{m}^{3}$.

Pumping water to header tanks consumed between 0.14 and $0.35 \mathrm{kWh} / \mathrm{m}^{3}$. A study made by Retamal et al. for RWH systems in Australia found figures ranging from $0.8 \mathrm{kWh} / \mathrm{m}^{3}$ to 1.6 $\mathrm{kWh} / \mathrm{m}^{3}$ (Retamal et al. 2009), but they were calculated for pressurised systems feeding points of use directly. The study concluded that theoretical energy consumptions (the ones calculated by the study) are smaller than measured consumptions usually because pumps are not working at their highest efficiency. According to this, pumping energy consumptions can be expected to be higher than the estimated by the RHO_mx model but lower than the values found by Retamal et al. (2009). Nevertheless, this underestimation affects all scenarios, and therefore, was not considered critical for final results.

Pumping increased CED in the RWH scenarios by less than $0.6 \%$ compared to scenario BASE.

\subsection{Cost}

RWH was found to be economically feasible for all scenarios and buildings except for the single-house and one of the high-rise housing buildings, where only scenario RWg returned a positive NPV.

The maximum potential saving was estimated for each building as the annual available rainfall times its corresponding water tariff. It was found that the higher the potential saving, the higher the NPV for scenarios RW1, RW2, and RW3, as shown in Fig. 5. Buildings with a saving potential equal to or higher than $£ 208$ per year $(\$ 4615 \mathrm{MXN})$ can be expected to yield positive NPV for scenario RW1, £156 per year ( $\$ 3456 \mathrm{MXN})$ for scenario RW2, and $£ 117$ per year $(\$ 2588 \mathrm{MXN})$ for scenario RW3. Scenario 5 has no standard curve because its harvesting capacity is constrained by the available storage space.

\subsection{Water Quality}

Water quality control can be an important limitation for scenario RW3, as rainwater and municipal water are stored in the same cistern. To mitigate this risk, filters and disinfection equipment must be designed to deal with contamination hazards like birds or pets' faeces (Adler et al. 2013; Meera and Ahammed 2006), inhabitants must be aware of the risk of modifying connections to rainwater downpipes, and maintenance must be flawless. Scenario RW2 mitigates quality risks by having independent storages for rainwater and municipal water, which eases maintenance works and isolation in case 
Fig. 5 Net Present Value (NPV) by maximum potential saving in annual water bills

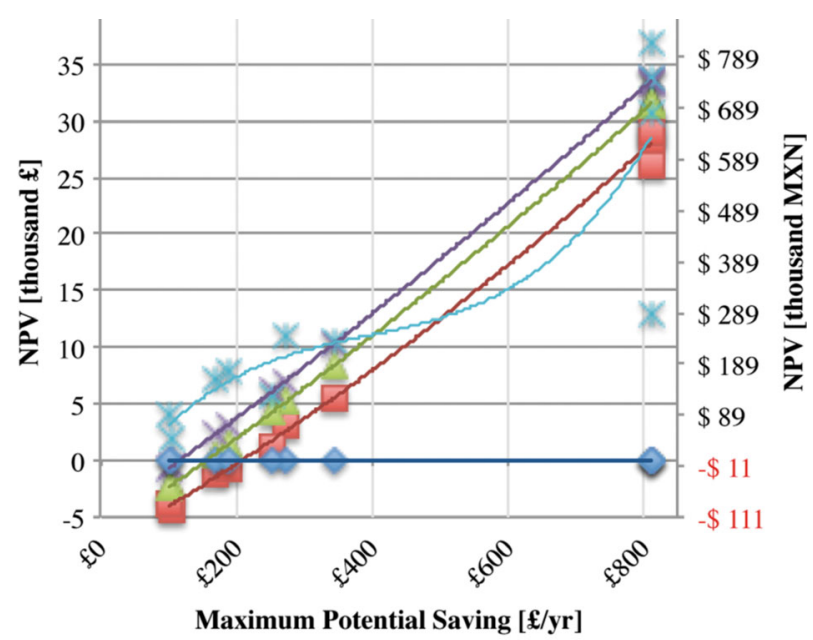

Scenario RW1

$\triangle$ Scenario RW2

$\times$ Scenario RW3

* Scenario RWg

$\diamond$ Scenario BASE

of contamination. Scenario RW1 eliminates this risk altogether by using rainwater only for non-potable uses.

\section{Sensitivity Analysis}

The reliability of results lies on the robustness of the input data used in the model and the algorithms it is built upon. Even though the model was built on standard international methodologies and inputs were carefully selected from published and official data, it is important to acknowledge that input parameters might have variations in time. To assess this, sensitivity analyses on variations of the main model inputs were made and are shown below.

\subsection{Water Demand}

Water consumption in Mexico City varies depending on personal habits and availability, having an average in 2012 of $122 \mathrm{~L}$ consumed per person per day (PIGOO 2013). To evaluate the system's sensitivity to water demand, the RHO_mx model was run again but decreasing by $25 \%$ the design daily supply required by the local norms, which was used in the first place to estimate the building's water demand.

It was found that decreasing water demand by $25 \%$ increased by $33 \%$ the ARWD ratio, and consequently GWP savings increased by $20 \%$ to $44 \%$ for the potable scenarios. The nonpotable scenario RW1 decreased its savings in buildings with an ARWD higher than $30 \%$. This was because by decreasing water demand less rainwater is consumed, and when the rainwater storage is full the rainwater that is not used overflows to the sewage. It would be necessary to enlarge the storage to harvest the same amount of rainwater, but that would distance GWP from its optimum point. 


\subsection{Municipal Infrastructure Improvements}

The effect of improving the municipal water network to lose only $20 \%$ of its water through leakages and treat $100 \%$ of the wastewater was analysed. It was found that even though energy to supply municipal water decreased by $66 \%$, implementing RWH reduced GWP in all buildings and scenarios by between $1.6 \%$ and $17.9 \%$.

\subsection{Clean Energy}

Electricity consumption was found to be the largest GWP contributor, therefore, it was important to analyse the effect of decreasing the electricity emissions factor. Halving the present factor from $0.79 \mathrm{kgCO}_{2} \mathrm{eq} / \mathrm{kWh}$ to $0.40 \mathrm{kgCO}_{2} \mathrm{eq} / \mathrm{kWh}$ reduced GWP savings by less than $50 \%$.

To accomplish the Mexican's government goal of halving GHG emissions by 2050 in relation to 2000 values (Cámara de Diputados 2012), it would be necessary to reduce the emission factor to $0.13 \mathrm{kgCO}_{2} \mathrm{eq} / \mathrm{kWh}$, according to an electricity mix study by Edgar García García and Morales-Acevedo (2014). Using this value to analyse RWH resulted in GWP increments by up to $13 \%$ in scenario RW1 and savings only in scenario RW3 and RWg by a maximum of $1.4 \%$ and $6.9 \%$, respectively. It would be necessary to modify this electricity mix also in material LCAs for an accurate comparison.

\section{Conclusions}

Results from scenarios and buildings tested by the RHO_mx model show RWH in Mexico City could reduce GHG emissions and mitigate flooding risk, making the city more resilient. All RWH scenarios analysed in this study resulted in lower GWP and CED than the nonrainwater-harvesting scenario BASE. RWH reduced by between $0.9 \%$ and $18.4 \%$ the GWP of the building's water system.

RWH is economically feasible if unsubsidised water and energy prices are considered, except for small systems like a house where water-bills savings do not offset extra costs. Buildings with a saving potential (annual available rainfall * water tariff) equal or higher than $£ 208$ per year ( $\$ 4615 \mathrm{MXN})$ can be expected to yield positive NPV.

Gravity fed wall-mounted tanks (scenario RWg) combined with natural infiltration areas or soakaway pits are recommended for high-rise buildings (five or more storeys) in areas of Mexico City where infiltration of rainwater into the aquifer is possible. Potable rainwater harvesting systems (scenarios RW2 and RW3) are recommended for buildings in lacustrine areas of the city, but maintenance should be flawless to ensure water quality. If the probability of water pollution is high, non-potable RWH systems (scenario RW1) are recommended, especially if the ARWD ratio is lower than $10 \%$. For the rest, infiltration should be preferred because infiltrated rainwater will eventually be extracted from the aquifer through wells (which have low energy consumption per $\mathrm{m}^{3}$ ), displacing water that would be imported from other basins, mitigating land subsidence and flooding risk.

Decreasing buildings' water consumption in Mexico City would bring a double benefit: GHG emissions would decrease as water demand decreases, and rainwater would cover a larger percentage of water demand hence decreasing even more municipal water consumption and its emissions. 
Even though RHO_mx does not analyse retrofitting, it can be presumed from results that GHG emissions from additional site adaptations will show relatively low differences in GWP and CED, since emissions from construction and raw materials account for less than $7 \%$ of the total lifecycle potential impacts.

A detailed measurement of harvested rain volumes and energy consumption in existing RWH systems of Mexico City is desired as a continuation of the present study.

Acknowledgments The present project was developed with the assistance of the Mario Molina Centre for Strategic Studies on Energy and Environment, a Mexican research centre aiming at bridging practical and indepth solutions between science and public policy to foster sustainable development.

Special recognition is given to the National Centre of Science and Technology (CONACyT) for funding this research.

\section{Compliance with Ethical standards}

Conflict of Interest No conflict of interest.

Open Access This article is distributed under the terms of the Creative Commons Attribution 4.0 International License (http://creativecommons.org/licenses/by/4.0/), which permits unrestricted use, distribution, and reproduction in any medium, provided you give appropriate credit to the original author(s) and the source, provide a link to the Creative Commons license, and indicate if changes were made.

\section{References}

Adler I, Hudson-Edwards KA, Campos LC (2011) Converting rain into drinking water: quality issues and technological advances. Water Sci Technol Water Supply 11:659. doi:10.2166/ws.2011.117

Adler I, Hudson-Edwards KA, Campos LC (2013) Evaluation of a silver-ion based purification system for rainwater harvesting at a small-scale community level. J Water Supply Res Technol 62:545-551. doi:10. 2166/aqua.2013.049

Amores MJ, Meneses M, Pasqualino J, Antón A, Castells F (2013) Environmental assessment of urban water cycle on Mediterranean conditions by LCA approach. J Clean Prod 43:84-92. doi:10.1016/j.jclepro.2012.12.033

Angrill S, Farreny R, Gasol CM, Gabarrell X, Viñolas B, Josa A, Rieradevall J (2011) Environmental analysis of rainwater harvesting infrastructures in diffuse and compact urban models of Mediterranean climate. Int J Life Cycle Assess 17:25-42. doi:10.1007/s11367-011-0330-6

Bates BC, Kundzewicz ZW, Wu S, Palutikof J (2008) 2008: climate change and water. Technical paper of the Intergovernmental Panel on Climate Change, Geneva

Burns E, Breña Puyol AF, Epinoza Hilario J, Garay JM, Espinoza Hilario DC, Gómez Reyes E, Moctezuma Barragán P, Raufflet E, Monroy Hermosillo O, Sánchez Díaz LF, Pulido Jiménez M, Seguin N (2010) Rethinking the basin: water-cycles management in The Valley of Mexico (repensar la cuenca: La gestión de ciclos del agua en el Valle de México). Universidad Autónoma Metropolitana, Mexico

Centro Mario Molina, 2011. Energetic evaluation of the present water systems in Mexico city and management proposals of its hydric resources (evaluación energética de los actuales sistemas de aguas urbanas y propuestas de manejo de los recursos hídricos en la ciudad de México). Mexico.

CFE, 2014. High consumption domestic tariff (tarifa doméstica de alto consumo) [WWW document]. Com. Fed. Electr. URL http://app.cfe.gob.mx/Aplicaciones/CCFE/Tarifas/Tarifas/Tarifas_casa.asp?Tarifa= DACAnual2003\&anio=2014 (accessed 7.31.14).

Chávez, A., 2014. PTAR will start running until 2015, says conagua (iniciará PTAR operaciones hasta el 2015, dice conagua) [WWW document]. Milenio.com. URL http://www.milenio.com/region/Iniciara-PTARoperaciones-dice-Conagua_0_289171138.html (accessed 1.15.15).

CONAGUA, 2009. Water statistics of the XIII hydrologic region, valley of Mexico waters (estadísticas del agua de la región hidrológico-administrativa XIII, aguas del Valle de México). Mexico City.

CONAGUA, 2010. Standard climate data by weather station (normales climatológicas por estación) [WWW document]. URL http://smn.cna.gob.mx/index.php?option=com_content\&view=article\&id=42\&Itemid=28 (accessed 7.7.14). 
CONAGUA, 2012. Infrastructure actions for drainage and water supply in The Valley of Mexico 2007-2012 (acciones de infraestructura de drenaje y abastecimiento de agua en el Valle de México 2007-2012).

CONAGUA, 2013. Situation of the subsector potable water, drainage and sanitation (situación del subsector agua potable, alcantarillado y saneamiento).

de Diputados C (2012) Climate change act (ley general de cambio climático). Diario Oficial de la Federación, Mexico

Banco de México, 2014a. Inflation (inflación) [WWW document]. Banco de México. URL http://www.banxico. org.mx/portal-inflacion/index.html (accessed 8.19.14).

Banco de México, 2014b. Securities market, interest rates (mercado de valores, tasas de interés) [WWW document]. Banco de México. URL http://www.banxico.org.mx/portal-mercado-valores/index.html (accessed 8.23.14).

DEFRA, 2014. Greenhouse gas conversion factor repository [WWW document]. Greenh. Gas Convers. Factor Repos. URL http://www.ukconversionfactorscarbonsmart.co.uk/LandingPage.aspx (accessed 7.17.14).

Devkota J, Schlachter H, Anand C, Phillips R, Apul D (2013) Development and application of EEAST: a life cycle based model for use of harvested rainwater and composting toilets in buildings. J Environ Manag 130: 397-404. doi:10.1016/j.jenvman.2013.09.015

Figueroa V. G.E., 1984. Case History No. 9.8. Mexico, D.F., Mexico, in: Poland, J.F. (Ed.), Guidebook to Studies of Land Subsidence due to Groundwater Withdrawal. UNESCO, pp. 217-232.

Fitzpatrick, C., 2009. MWH leads rainwater harvesting project [WWW document]. Mag. Int. Water Assoc. URL http:/www.iwapublishing.com/template.cfm?name=w21prodnews040209e (accessed 8.18.14).

García ERS, Morales-Acevedo A (2014) Optimizing the energy portfolio of the Mexican electricity sector by 2050 considering $\mathrm{CO}_{2}$ eq emissions and life cycle assessment. Energy Procedia 57:850-859. doi:10.1016/j. egypro.2014.10.294

Gobierno D.F., 2004. Complementary technical norms for design and excecution of hydraulic systems (normas técnicas complementarias para el diseño y ejecución de obras e instalaciones hidráulicas), Mexico.

Gobierno D.F., 2005. Official Gazette of the Federal District No. 41, April 8th 2005 (Gaceta Oficial del Distrito Federal No. 41, 8 de abril de 2005, Décima quinta época), Gaceta Oficial del Distrito Federal. Gobierno del Distrito Federal, Mexico.

Gobierno D.F., 2013. Tax Code of the Federal District (Código Fiscal del Distrito Federal), 2013.

Gwenzi W, Nyamadzawo G (2014) Hydrological impacts of urbanization and urban roof water harvesting in water-limited catchments: a review. Environ Prog 1:573-593. doi:10.1007/s40710-014-0037-3

Hammond, G., Jones, C., 2008. Inventory of Carbon and Energy (ICE), 1.6a ed. University of Bath.

INEGI, 2013. Statistical and geographical log-book of the metropolitan area of The Valley of Mexico (cuaderno estadístico y geográfico de la zona metropolitana del Valle de México 2013). Mexico City.

Itten, R., Frischknecht, R., Stucki, M., 2014. Life cycle inventories of electricity mixes and grid. Paul Scherrer Inst.

Lemos D, Dias AC, Gabarrell X, Arroja L (2013) Environmental assessment of an urban water system. J Clean Prod 54:157-165. doi:10.1016/j.jclepro.2013.04.029

Meera V, Ahammed MM (2006) Water quality of rooftop rainwater harvesting systems: a review. J Water Supply Res Technol 55:257-268. doi:10.2166/aqua.2006.008

PIGOO, 2013. Management indicators programme for operation utilities (programa de indicadores de gestión de organismos operadores) [WWW document]. Programa Indicadores Gestión Org. Operadors del Inst. Mex. Tecnol. del Agua. URL http://www.pigoo.gob.mx/index.php?option=com_wrapper\&view= wrapper\&Itemid=1252 (accessed 7.8.14).

Racoviceanu AI, Karney BW (2010) Life-cycle perspective on residential water conservation strategies. J Infrastruct Syst ASCE 16:40-49

Retamal, M., Glassmire, J., Abeysuriya, K., Turner, A., White, S., 2009. Investigation into the energy implications of household rainwater systems. Sydney.

Romero Lankao P (2010) Water in Mexico city: what will climate change bring to its history of water-related hazards and vulnerabilities? Environ Urban 22:157-178. doi:10.1177/0956247809362636

SACM, 2012. The big water challenge in Mexico city (El gran reto del agua en la ciudad de México).

SACM, 2014. Rainwater reuse alternative system calculation giude (guía para el cálculo del sistema alternativo de reuso de agua pluvial). Mexico.

UNEP, 2015. Rainwater Harvesting and Utilisation. An Environmentally Sound Approach for Sustainable Urban Water Management: An Introductory Guide for Decision-Makers [WWW Document]. United Nations Environ. Program. Div. Technol. Ind. Econ. URL http://www.unep.or.jp/Ietc/Publications/Urban/ UrbanEnv-2/index.asp (accessed 8.30.14).

Vieira AS, Beal CD, Ghisi E, Stewart RA (2014) Energy intensity of rainwater harvesting systems: a review. Renew Sust Energ Rev 34:225-242. doi:10.1016/j.rser.2014.03.012

Ward S, Memon FA, Butler D (2012) Performance of a large building rainwater harvesting system. Water Res 46: 5127-5138. doi:10.1016/j.watres.2012.06.043

Zhang, Y., 2009. Sustainability oriented feasibility model for construction decision making: water recycling cases in buildings. 